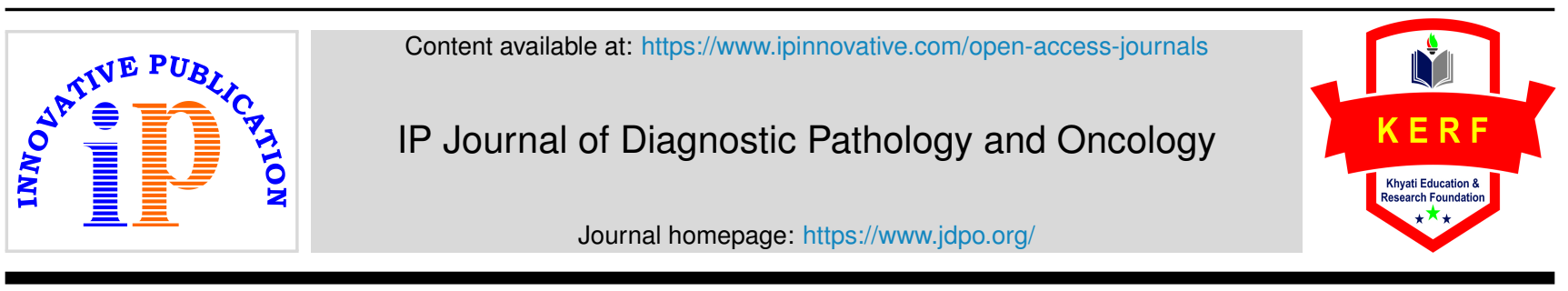

Original Research Article

\title{
Role of exfoliative cytology in diagnosis of oral lesions: With special reference to rule out malignancy
}

\author{
Shoborose Tantray ${ }^{1, *}$, Seema Sharma ${ }^{1}$ \\ ${ }^{1}$ Dept. of Oral and Maxillofacial Pathology and Microbiology, Santosh Dental College and Hospital, Ghaziabad, Uttar \\ Pradesh, India
}

\section{A R T I C L E I N F O}

\section{Article history:}

Received 03-05-2021

Accepted 21-05-2021

Available online 14-06-2021

Keywords:

Exfoliative cytology

Leukoplakia

Oral malignancy

Cancer

\begin{abstract}
A B S T R A C T
Background: Oral malignancy is very common in India because of the excessive use of tobacco chewing and smoking. Procedure of Cytology is inexpensive and unchallenging that can be carried out effortlessly at outdoor patient department to diagnose malignancy at early stage.

Aim and Objectives: The present study was carried out to detect cancer pre-invasive stage by use of exfoliative cytology and to probe the probability of using this technique in diagnosis of other oral lesions thought as premalignant ones.

Materials and Methods: A total 102 patients referred from OPD and Surgery Department of a Private Hospital, Dispensary and Cancer Hospital, Delhi, between August 2019 to April 2020 , were included in this study. Two smears were taken by scrap method, from each patient and were prepared after air dried stained with RAPID PAP stain. According to the Papanicolaou classification the smear were assessed along with clinical, epidemiological data and classified in group I to IV.

Results: In our result 25 cases were normal, leukoplakia 47 cases with mean age 47.5 years, $85 \%$ male. Predominantly 53\% Smear show anucleated squames. 06 cases were Oral submucous fibrosis ,66.7\% were female with mean age 38.3 years and, the present smear revealed rarification of nuclei in $66 \%$ cases. 02 cases of mucosal hyperemia (Erythema), one-one case of traumatic ulcer and granular buccal mucosa were included. Out of 12 cases of malignancy, male were $75 \%$ with mean age of 46 year. Buccal mucosa and tongue were the common site with incidence of $60 \%$. The smear showed inflammatory cells in $100 \%$, malignant cells in $75 \%$ cases either in groups or in singles. The third type of cells $60 \%, 37 \%$ the undifferentiated cells, and 5\% cases Tadpole cells. In this study $75 \%$ cases were positive for cancer, $10 \%$ were suspicious for cancer and remaining $15 \%$ were given as negative for cancer.

Conclusion: For the diagnosis of presence or absence of malignancy in a lesion with high accuracy rate Cytology is reliable diagnostic tool. The oral cytologic technique is effortless to do and can provide the help of surgeon/physician, instead of performing an invasive procedure, like a biopsy, or desire more information regarding a lesion before referring the patient.
\end{abstract}

(C) This is an open access article distributed under the terms of the Creative Commons Attribution License (https://creativecommons.org/licenses/by/4.0/) which permits unrestricted use, distribution, and reproduction in any medium, provided the original author and source are credited.

\section{Introduction}

Exfoliative Cytology has been broadly confirmed as a tool in the early detection of malignancy and has taken its appropriate position besides the other known branches of hospital diagnostic services. ${ }^{1}$ Any laboratory method must meet three principle requirements, to achieve wide

\footnotetext{
* Corresponding author.

E-mail address: shabroztantray@gmail.com (S. Tantray).
}

acceptance and these are (a) the method should be easy to perform, (b) it should give minimal discomfort and disadvantage to the patient (c) it must provide exact outcome. The method of cyto-diagnosis meets these three requirements very well and that is why it has gained popularity with in such a short period of time since its introduction by George N. Papanicolaou. ${ }^{2}$ Clinical cytology, in the hands of well trained personnel now possess a sensitivity of 92 to $100 \%$ while its specificity has risen to 
somewhere between 97 to $100 \%$ (Nils G. Stromby,1999). ${ }^{2}$ It has been reported that majority of the carcinomas of the oral cavity are of well differentiated squamous cell type. In these type of malignant cases the malignant cells have a characteristic cytologic appearance and are quite easily recognized. ${ }^{3}$ This guarantee that cyto-diagnosis is likely to yield a high degree of accuracy in cases of oral malignancies, cytological diagnosis is still in its infancy for the recognition of premalignant lesion in various areas of the human body. From the results achieved by workers like Sandler it seems there is great promise in its use in oral premalignant lesions and in-situ carcinomas. ${ }^{3-7}$ the oral cancers as in other regions of the body freely exfoliate and, therefore, smears prepared from regions that harbor a cancer are usually rich in number with variety of exfoliated malignant cells. ${ }^{8}$ Silverman, Becks and Farber (1977) have suggested that cytological technique, being simple and noninvasive procedure, has the advantage of doing away with many undesirable features of a biopsy and that offers a easy yet reliable method of great predictability in cancer detection programme. ${ }^{9}$ It was with this view that the present work had been undertaken. The present research has been taken to find out whether cancer can be detected in its preinvasive stage by use of exfoliative cytology, in addition an effort has been made to explore the possibility of using this technique in detection of other oral pre-malignant lesions.

\section{Materials and Methods}

The present study was carried out over a period, from August 2019 to April 2020. The material for our study was collected from patients attending the outpatient Department of the Private Hospital including the E.N.T. and surgery department of a dispensary as well as cancer research institute Delhi for various complaints pertaining to oral cavity. Informed expressed consent was taken from all patients before including them in study. Ethical Committee approval was also taken out before starting study. In every case a detailed general oral examination was done and positive findings along with a brief clinical history were noted down most of the cases required no prior preparation. Some of the cases were found to be covered with debris or slough, surfaces of such lesions were first cleaned by wiping with a piece of gauge moistened in normal saline solution and then the scraping was done. The cases which were highly keratinized in those lesions the keratinized surface was removed by scraping it with a wooden spatula. In case of the lip lesions, the involved areas were first soaked with a piece of wet gauge for about 15 minutes before taking the scraped specimen. Carefully labelled slide was held between the left thumb and the fore finger, the angle of the mouth was drawn laterally with the help of left little finger, a wooden tongue depressor which had previously been soaked in tap water was held in the right hand and with its help the entire surface of the lesion was scraped vigorously using the edge of the wet tongue depressor several times but mostly in one direction. Scraping thus picked up on the edge of the tongue depressor were spread evenly and rapidly over the glass slide and the slide was immediately fixed with spray fixative given in Rapid PAP kit. Two smears were always prepared from each patient. The smears were allowed to air dry. In the present study, prepared smears were stained by Rapid PAP kit. The slides were mounted with cover slip using a drop of D.P.X. Mountant.

After screening cytologic smears were classified according to Papanicolaou's $(1960)^{2}$ classification: Class I (Normal) - Only Normal cells were observed

Class II (atypical) - Presence of minor atypia, but no evidence of malignancy.

Class III (Intermediate) - The cells display wide atypia that may be suggestive of malignancy, but they are not clear cut cancer and represent precancerous lesions or in situ carcinoma.

Class IV (Suggestive of cancer) - A few epithelial cells with malignant characteristics or cells with borderline characteristics.

Class V - Positive cancer cells, that are obviously malignant. $^{2}$

\section{Result}

A total of 204 oral mucosal smear from 102 patients were taken, in which 25 were normal group. The normal group was taken as control. The control group consists of people with out any complain, clinical examination the oral mucosa appeared absolutely normal. Cases with history of tobacco chewing and smoking were not included in the control group. (Table 1) In our study the maximum age group of Leukoplakia was $31-40$ years observed in $61.7 \%$ cases with mean age of 47.5 and $85 \%$ cases were male. In Leukoplakia $97.8 \%$ cases were either tobacco chewer or smokers and $12.7 \%$ patients came with complaint directly related to the leukoplakic patch while remaining were unaware with the problem. $87.2 \%$ the most common site of involvement was buccal mucosa. (Table 2) No malignant cells were evident on any smear of Leukoplakia. Anucleated squames were present in 53\% cases. In 38\% Leukoplakia cases, mild degree acidophilia and moderate acidophilia in $36 \%$ cases was seen. Karyorrhexis $25 \%$, prominent nuclear membrane $11 \%$, prominent nucleoli $6 \%$ and rarification of nuclei $4 \%$ cases were observed. (Table 3) 06 cases of submucous fibrosis were included in study. 50\% were age group of $31-40$ years (mean age 38.3 years) and $66.7 \%$ female. All cases were with complaint of restricted movement of lower jaw and inability to open mouth completely. No history of tobacco or betel nut chewing among female patients. Cytologically smear showed $66 \%$ rarification of nuclei, $50 \%$ irregular maturation of cytoplasm, and 50\% mild atypia cases. No malignancy was evident in the osmf cases. 
Table 1: Age and Sex Distribution of Cases.

\begin{tabular}{|c|c|c|c|c|c|c|c|}
\hline $\begin{array}{l}\text { Age } \\
\text { group }\end{array}$ & Normal & Leukoplakia & $\begin{array}{l}\text { Oral } \\
\text { submucous } \\
\text { fibrosis }\end{array}$ & $\begin{array}{l}\text { Mucosal } \\
\text { hyperemia }\end{array}$ & $\begin{array}{l}\text { Traumatic } \\
\text { ulcer }\end{array}$ & $\begin{array}{l}\text { Granular } \\
\text { mucosa }\end{array}$ & Carcinoma \\
\hline $20-30$ & $\begin{array}{l}M=2(8 \%) \\
F=0 T=2 \\
(8 \%\end{array}$ & $\begin{array}{l}\mathrm{M}=3(6.38 \%) \\
\mathrm{F}=1(2.12 \%) \\
\mathrm{T}=4(8.5 \%)\end{array}$ & $\begin{array}{l}\mathrm{M}=0 \mathrm{~F}= \\
1(16.7 \%) \mathrm{T}= \\
1(16.7 \%)\end{array}$ & $\begin{array}{l}M=0 \\
F=0 \\
T=0\end{array}$ & $\begin{array}{l}M=0 \\
F=0 \\
T=0\end{array}$ & $\begin{array}{l}M=0 \\
F=0 \\
T=0\end{array}$ & $\begin{array}{l}M=0 \\
F=0 \\
T=0\end{array}$ \\
\hline $31-40$ & $\begin{array}{l}\mathrm{M}=1(4 \%) \\
\mathrm{F}=2(8 \%) \\
\mathrm{T}=3(12 \%)\end{array}$ & $\begin{array}{l}\mathrm{M}=10(21.2 \%) \\
\mathrm{F}=1(2.12 \%) \\
\mathrm{T}=11(23.4 \%)\end{array}$ & $\begin{array}{l}\mathrm{M}=1(16.7 \%) \\
\mathrm{F}=2(33.3 \%) \\
\mathrm{T}=3(50 \%)\end{array}$ & $\begin{array}{l}M=0 \\
F=0 \\
T=0\end{array}$ & $\begin{array}{l}M=0 \\
F=0 \\
T=0\end{array}$ & $\begin{array}{l}\mathrm{M}=1(100 \%) \\
\mathrm{F}=0 \\
\mathrm{~T}=1(100 \%)\end{array}$ & $\begin{array}{l}\mathrm{M}=3(15 \%) \\
\mathrm{F}=2(10 \%) \\
\mathrm{T}=5(25 \%)\end{array}$ \\
\hline $41-50$ & $\begin{array}{l}\mathrm{M}=6(24 \%) \\
\mathrm{F}=6(24 \%) \\
\mathrm{T}=12(48 \%)\end{array}$ & $\begin{array}{l}\mathrm{M}=14(29.7 \%) \\
\mathrm{F}=4(8.5 \%) \\
\mathrm{T}=18(38.2 \%)\end{array}$ & $\begin{array}{l}M=0 \\
F=1(16.7 \%) \\
T=1(16.7 \%)\end{array}$ & $\begin{array}{l}M=0 \\
F=0 \\
T=0\end{array}$ & $\begin{array}{l}\mathrm{M}=0 \\
\mathrm{~F}=1(100 \%) \\
\mathrm{T}=1(100 \%)\end{array}$ & $\begin{array}{l}M=0 \\
F=0 \\
T=0\end{array}$ & $\begin{array}{l}\mathrm{M}=4(20 \%) \\
\mathrm{F}=2(10 \%) \\
\mathrm{T}=6(30 \%)\end{array}$ \\
\hline $51-60$ & $\begin{array}{l}\mathrm{M}=4(16 \%) \\
\mathrm{F}=4(16 \%) \\
\mathrm{T}=8(32 \%)\end{array}$ & $\begin{array}{l}\mathrm{M}= \\
8(17.02 \%) \mathrm{F}= \\
1(2.12 \%) \mathrm{T}= \\
9(19.14 \%)\end{array}$ & $\begin{array}{l}\mathrm{M}=1(16.7 \%) \\
\mathrm{F}=0 \\
\mathrm{~T}=1(16.7 \%)\end{array}$ & $\begin{array}{l}\mathrm{M}=1(50 \%) \\
\mathrm{F}=1(50 \%) \\
\mathrm{T}=2(100 \%)\end{array}$ & $\begin{array}{l}M=0 \\
F=0 \\
T=0\end{array}$ & $\begin{array}{l}M=0 \\
F=0 \\
T=0\end{array}$ & $\begin{array}{l}\mathrm{M}=4(20 \%) \\
\mathrm{F}=2(10 \%) \\
\mathrm{T}=6(30 \%)\end{array}$ \\
\hline $61-70$ & $\begin{array}{l}M=0 \\
F=0 \\
T=0\end{array}$ & $\begin{array}{l}M=3(6.38 \%) \\
F=0 \\
T=3(6.38 \%)\end{array}$ & $\begin{array}{l}\mathrm{M}=0 \mathrm{~F}=0 \mathrm{~T} \\
=0\end{array}$ & $\begin{array}{l}M=0 \\
F=0 \\
T=0\end{array}$ & $\begin{array}{l}\mathrm{M}=0 \mathrm{~F}=0 \mathrm{~T} \\
=0\end{array}$ & $\begin{array}{l}M=0 \\
F=0 \\
T=0\end{array}$ & $\begin{array}{l}\mathrm{M}=3(15 \%) \\
\mathrm{F}=0 \\
\mathrm{~T}=3(15 \%\end{array}$ \\
\hline $71-80$ & $\begin{array}{l}M=0 \\
F=0 \\
T=0\end{array}$ & $\begin{array}{l}\mathrm{M}=2(4.25 \%) \\
\mathrm{F}=0 \\
\mathrm{~T}=2(4.25 \%\end{array}$ & $\begin{array}{l}M=0 \\
F=0 \\
T=0\end{array}$ & $\begin{array}{l}M=0 \\
F=0 \\
T=0\end{array}$ & $\begin{array}{l}M=0 F=0 \\
T=0\end{array}$ & $\begin{array}{l}M=0 \\
F=0 \\
T=0\end{array}$ & $\begin{array}{l}M=0 \\
F=0 \\
T=0\end{array}$ \\
\hline $\begin{array}{l}\text { Total } \\
102\end{array}$ & $\mathrm{~N}=25$ & $\mathrm{~N}=47$ & $\mathrm{~N}=6$ & 2 & 1 & $\mathrm{~N}=1$ & 38 \\
\hline $\begin{array}{l}\text { Mean } \\
\text { age }\end{array}$ & 45.2 & 47.5 & 38.3 & 55 & 50 & 38 & 46.06 \\
\hline
\end{tabular}

Table 2: Symptoms of Leukoplakia in 47 cases

\begin{tabular}{lc}
\hline Symptoms & No of cases \\
Recurrent ulcer & $3(6.28)$ \\
Excessive salivation & $2(4.25)$ \\
Itching in oral cavity & $1(2.21 \%)$ \\
Burning mouth & $1(2.21 \%)$ \\
No symptoms & $1(2.21 \%)$ \\
Site of involvement of mouth in 20 cases & $39(82.9 \%)$ \\
Clinically suspected to be malignancy & $\mathrm{N}=47$
\end{tabular}

\section{Location No of cases}

\begin{tabular}{lc}
\hline Location & No of cases \\
Buccal mucosa & $7(35 \%)$ \\
Tongue & $5(25 \%)$ \\
Alveolar margin & $3(15 \%)$ \\
Tonsil & $2(10 \%)$ \\
Base of tongue and tonsil & $1(5 \%)$ \\
Alveolar margin and cheek & $1(5 \%)$ \\
Lip & $1(5 \%)$ \\
\hline
\end{tabular}

In our study mucosal hyperemia (erythema) 02 cases were included. 01 case was male patient having a history of chronic smoking also there was presence of erythematous patche on the palate. The second case was female patient with no history of tobacco chewing. Smears from these
Table 3: Cytological observation in Leukoplakia

\begin{tabular}{lc} 
Anucleated squames & $\mathbf{5 3 \%}$ cases \\
mild degree acidophilia & $38 \%$ \\
moderate acidophilia & $36 \%$ \\
Karyorrhexis & $25 \%$ \\
Prominent nuclear membrane & $11 \%$ \\
prominent nucleol & $06 \%$ \\
rarificationof nuclei & $04 \%$ \\
\hline
\end{tabular}

Table 4: Cytological observation in 06 cases of Submucous fibrosis

\begin{tabular}{lc}
\hline Rarification of nuclei & $\mathbf{6 6 \%}$ cases \\
Irregular maturation of cytoplasm & $50 \%$ \\
Mild atypia & $50 \%$ \\
Malignancy & $0 \%$ \\
\hline
\end{tabular}

lesions revealed increased number of superficial cells and a fair number of polymorphonuclear cells.

One female patient present with a chronic traumatic ulcer on her upper lip was also studied. Smears revealed mild degree of dyskaryosis in epithelial cells. 01 male patient having granular buccal mucosa was also included in the present study, smears prepared from mucosal surface did not reveal any significant abnormality.

In this study we found twenty cases of the cancer with maximum age incidence 41-60 years (mean age 46 years) 


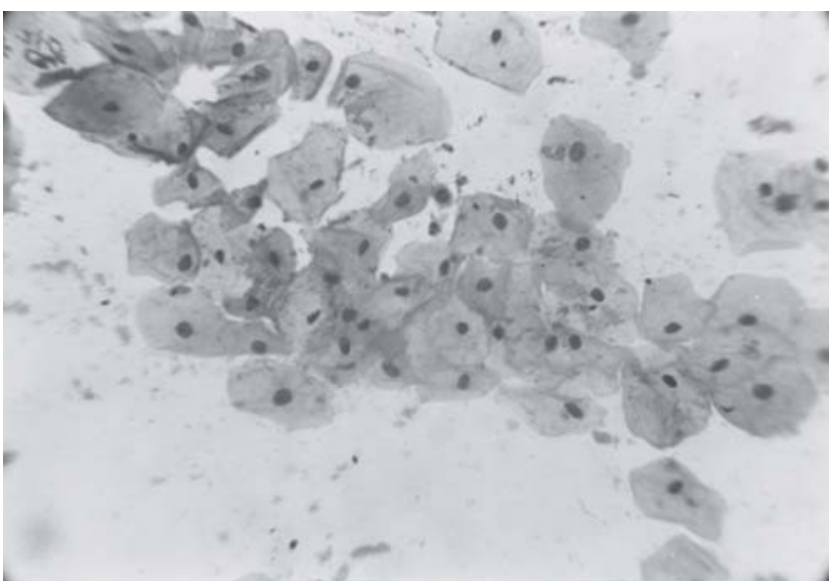

Fig. 1: Normal Buccal Smear(PAP Stain)

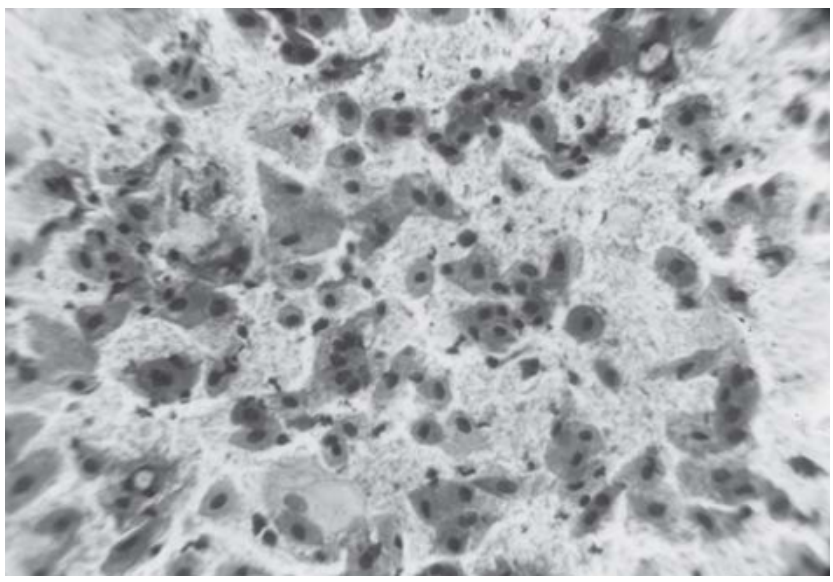

Fig. 2: Mild Dysplasia (Pap stain)

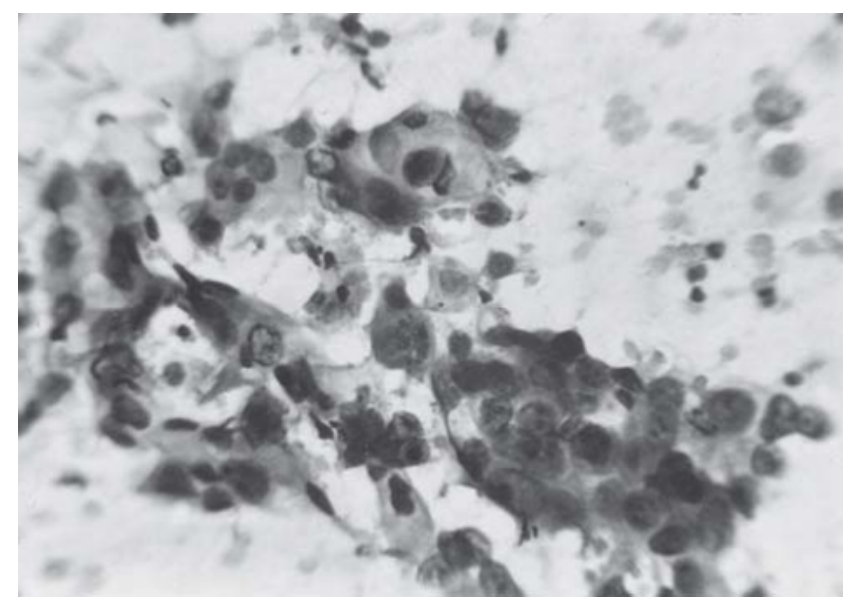

Fig. 3: Moderate Dysplasia (Pap stain)

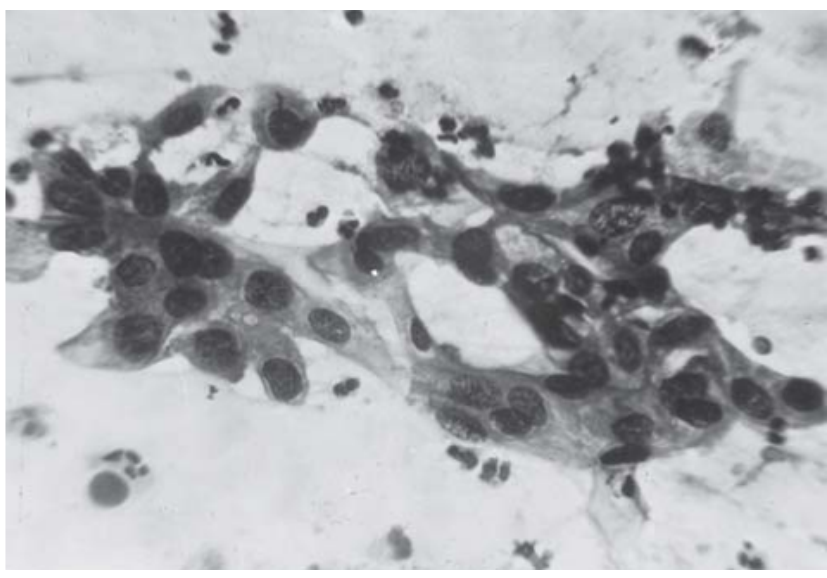

Fig. 4: Severe Dysplasia (Pap stain)

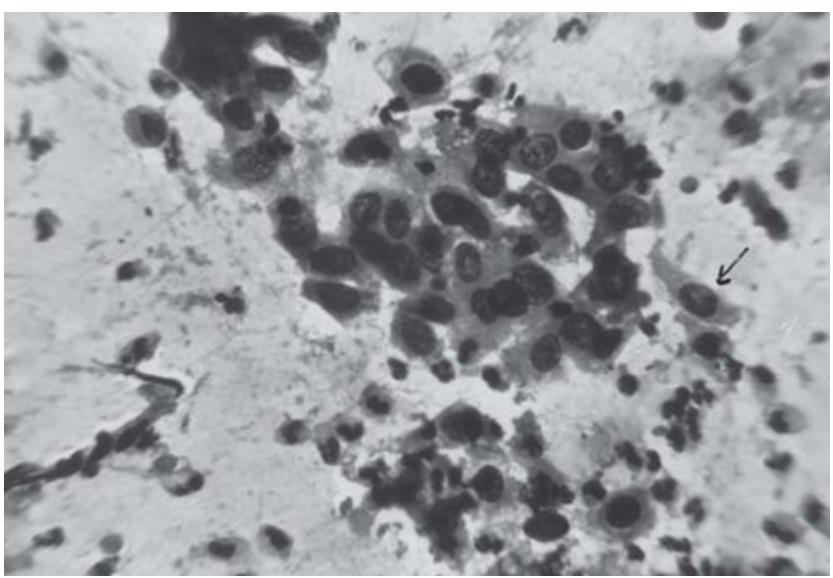

Fig. 5: Oral Squamous cell carcinoma (Pap stain)

and $70 \%$ were male and $100 \%$ cases with the history of tobacco chewing or smoking. The most common sites were cheek and tongue with incidence of $60 \%$. The smear showed inflammatory cells in $100 \%$, malignant cells in $75 \%$ cases either in groups or in singles. The third type of cells (cells having stand and clumps of nuclear chromatin, unevenly deposited at nuclear borders, irregular but well defined cytoplasmic borders and increased nuclear cytoplasmic ratio) were observed in $60 \%$ cases. The undifferentiated cells (cells in whom cellular borders are absent, nuclei are hyperchromatic, irregular in size and shape, chromatin arrangement in abnormal and nuclear borders are very sharp) were observed in $37 \%$ cases. Tadpole cells were least observed only in $5 \%$ cases.

Out of 20 clinically cancer suspected individuals, 75\% were positive for cancer, $10 \%$ were suspicious for cancer and remaining $15 \%$ were given as negative for cancer. 


\section{Discussion}

In our study the maximum age incidence in $61.7 \%$ cases of Leukoplakia was 31-40 years. Tieche (1965) observed $80-90 \%$ cases were above 40 years. ${ }^{10} 85 \%$ Majority cases were male in present study. In (1961) Shafer and Waldron made similar observation in 321 cases among these cases $70 \%$ were males. ${ }^{10,11}$ Buccal mucosa and alveolar mucosa were most common site of involvement of Leukoplakia by Tieche $(1965)^{10}$ similar observation $87.2 \%$ were obtained in our study . On microscopy, $74 \%$ of cases of Leukoplakia revealed predominant acidophilic character of cytoplasm in exfoliated cells and $51 \%$ of cases showed pyknotic nuclei, which is similar to observation by (1954) Wahi and Gupta approximately $75 \%$ of exfoliated superficial cells. ${ }^{12}$ Another significant finding was Anucleated squames in present study it was $53.2 \%$, while Montgomery and Von Hamm (1951A) were so impressed with the findings of Anucleated squames that they thought it to be almost diagnostic of the leukoplakic lesions. ${ }^{13}$ In case of advanced Leukoplakia, varying degree of nuclear atypia of exfoliated cells in smear were observed. ${ }^{14,15}$ In the present study $11 \%$ cases of leukoplakia, revealed moderate degree of nuclear atypia. 50\% submucous fibrosis cases were in age group of 31-40 years and $66.7 \%$ were female in the present study while in previous studies this was similar. In (1954) Sirsat and Khanolkar in their study of 40 cases reported 18 (45\%) female and $22(55 \%)$ male and Joshi et al (1953) cited by Sirsat and Khanolkar (1957), out of 41 cases 19 (46.3\%) were male and $22(53.7 \%)$ were females. ${ }^{16}$

An interesting finding in the smears from these areas was finding of rarified nuclei in $66 \%$ of cases. In 1955 Wahi and Kehar ${ }^{15}$ have reported $68-82 \%$ of rarified nuclei in cyanophilic cells. In (1956) Peters and Rysinghani also have similar observation. They considered it, significant finding as far as the cytological diagnosis of oral submucous fibrosis was concerned. ${ }^{14}$ Use of exfoliative cytology and cytoanalysis is a useful early diagnostic method for epithelial atypia and for oral lesion. ${ }^{17}$ There were 20 cases in this series, which were suspected to be of cancer on clinical examination. $70 \%$ patient were male and $60 \%$ in the age group of 41-60 years, with mean age of 46 years. In 1965 Tieche reported average age incidence was 55 years and $80-85 \%$ were male. ${ }^{10}$ That may be because of excessive tobacco chewing and smoking in India. The third type of cells were the most commonly observed malignant cells in the present study, it was seen in $60 \%$ of cases. The undifferentiated cells were comparatively less frequently observed $(33 \%)$. Tadpole cells were the least commonly encountered cells and seen only in one case. King (1962) found fiber cells and tadpole cells only in 2 cases of his series. "Third type" differentiated cells were commonly seen. ${ }^{18}$ Cawson (1960) also found tadpole cell less common in smears of oral carcinoma (only in 1 case). ${ }^{19}$ Abnormally large nucleoli were seen in $66 \%$ of smears from patient suffering from oral carcinoma in our study. Montgomery found prominent nucleoli from $86 \%$ of such smears. ${ }^{20}$ Prominent nuclei were considered to be a common observation in smears from cases of carcinoma of mouth by many workers. ${ }^{8,9,19,21}$

\section{Conclusion}

Cytological diagnosis is essential for the diagnosis of oral lesions, especially in distinguishing benign lesions from malignant ones, it is important for treatment as well as for clinical and epidemiological research including the study of prognosis. So far as diagnosis of presence or absence of malignancy in a lesion is concerned with high accuracy rate in diagnosing oral cancer cytology is considered as a reliable diagnostic tool. This procedure is not intended to replace tissue biopsy, but it is a valuable supplement to tissue biopsy. Indications for its use include oral mucosal lesions, and follow up for patient with a history of either a premalignant or malignant lesion. The oral cytologic technique is easy to do and can provide help to the surgeon / physician, in cases where he/she might hesitate to perform an invasive procedure, like a biopsy.

\section{Source of Funding}

No financial support was received for the work within this manuscript.

\section{Conflicts of Interest}

There are no conflicts of interest.

\section{References}

1. American Cancer Society: Cancer Facts and Figures 2005. Atlanta, Ga: American Cancer Society, 2005. Also available online. Last accessed May 20, 2005;

2. Stromby NG. Experience with buccal smears in the general cytopathology laboratory. Cancer. 1999;23:23-6.

3. Anderson WAD. Pathology. In: 10th Edn. St. Louis, M.O. the C.V. Mosby Company; 1996. p. 405-6.

4. Sandler HC. The detection of early cancer of the mouth by exfoliative cytology. Acta Cytol. 1961;5:191-4.

5. Sandler HC. Oral exfoliative cytology. Veterans Administration Cooperative study. 1962;.

6. Sandler HC. Veterans Administration Co-operative study of oral exfoliative cytology. Acta Cytol. 1963;7:180-2.

7. Sandler HC. Reliability of Oral Exfoliative Cytology for Detection of Oral Cancer. J Amer Dent Ass . 1964;68(4):489-99. do1:10.14219/jada.archive.1964.0123.

8. Peters H. Cytologic smears from the mouth: Cellular changes in disease and after radiation. Am J Clin Path. 1958;29:219.

9. Silverman S, Becks H, Farber SM. The diagnostic value of intra-oral cytology. J Dent Res. 1977;37:195-205.

10. Tiecke RW. Oral Pathology, New York. The Blakiston Division. McGraw Hill Book Co; 1965. p. 623-5.

11. Shafer WG, Hine MK, Levy BM. A text book of oral pathology. In: 2nd Edn. Philadelphia, Pa., W.B. Saunders Company; 1963. p. 465-7.

12. Wahi PN, Gupta K. Exfoliative cytology in diagnosis of carcinoma of oral cavity. J Ind Med Ass. 1954;23:425.

13. Montgomery PW, Haam EV. A Study of the Exfoliative Cytology of Oral Leucoplakia. J Dent Res . 1951;30(2):260-4. 
dol:10. 1770022034550300021601

14. Peters H, Rysinghani K. The cytologic interpretation of mouth smears. J Ind Med Ass. 1956;27:231-6.

15. Wahi PN, Kehar U. Morphological and cytochemical studies of precancerous lesions of oral cavity. Acta Cytol. 1966;10:173-8.

16. Sirsat SM, Khanolkar VR. Histochemical and electron microscopic study of submucous fibrosis of the palate. Ind $J$ Path \& Bact. 1957;73:439-42.

17. Ahmed HG, Idris AM, Ibrahim SO. Study of oral epithelial atypia among Sudanese tobacco users by exfoliative cytology. Anticancer Res. 2003;23:1943-9.

18. King $\mathrm{OH}$. The cytology of common and uncommon oral malignancies. Acta Cytol. 1962;6:348-54.

19. Cawson RA. The cytological smear in diagnosis of oral cancer. $\mathrm{Br}$ Dent J. 1960;108:294.

20. Montgomery PW. A Study of Exfoliative Cytology of Normal Human Oral Mucosa. J Dent Res . 1951;30(1):12-8.

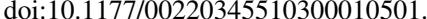

21. Sandler HC, Stahl SS. Exfoliative cytology; a diagnostic aid in the detection of oral neoplasms. J Oral Surg. 1958;16:414.

\section{Author biography}

Shoborose Tantray, Senior Lecturer

Seema Sharma, Professor and HOD

Cite this article: Tantray S, Sharma S. Role of exfoliative cytology in diagnosis of oral lesions: With special reference to rule out malignancy. IP J Diagn Pathol Oncol 2021;6(2):84-89. 